\title{
Impact assessment and public outreach strategies of local governments
}

\author{
S. Conway ${ }^{1}$, P. Washeba ${ }^{2} \&$ I. Navis ${ }^{3}$ \\ ${ }^{1}$ Urban Environmental Research, LLC, U.S.A. \\ ${ }^{2}$ Avnet, Inc., U.S.A. \\ ${ }^{3}$ Clark County Department of Comprehensive Planning Nuclear Waste \\ Division, U.S.A.
}

\begin{abstract}
In 1987, Clark County was designated by the United States Congress and the U.S. Department of Energy as an "affected unit of local government" under the Nuclear Waste Policy Act, as amended. The Nuclear Waste Policy Act was designed to establish a location for a geologic high-level nuclear waste repository. Under the provisions of the Act, Clark County is permitted the opportunity to, among other things, conduct impact assessment studies and prepare reports to articulate the findings of those studies. Clark County staff and consultants have developed impact assessment studies and prepared reports in several key socioeconomic areas.

This paper summarizes the potential socio-economic impacts that have been identified as part of Clark County's Nuclear Waste program. These findings were incorporated into Clark County's Impact Assessment Report on the Yucca Mountain Program that was submitted to the Department of Energy. The Impact Assessment Report has been distributed in paper and compact disk format, as well as being placed on the Department of Comprehensive Planning Website.

Keywords: stigma, hazardous waste, nuclear, socio-economic, risk perception.
\end{abstract}

\section{Introduction}

The Nuclear Waste Policy Act (NWPA) was designed to establish a location for a geologic high-level nuclear waste repository. In 1987, Clark County was designated by the United States Congress and the U.S. Department of Energy as an "affected unit of local government" (AULG) under the Nuclear Waste Policy 
Act, as amended (NWPAA). Under the provisions of the NWPAA, AULG's are authorized to conduct a broad range of activities in conjunction with DOE's site characterization activities at Yucca Mountain. These activities include reviewing and commenting on various U.S. Department of Energy (DOE) documents; independent socio-economic, environmental and technical impact analysis; and, public outreach and information dissemination.

This paper summarizes the results of the socio-economic impact assessment studies conducted by Clark County staff and consultants. The results that were incorporated into Clark County's Impact Report were submitted to the Secretary of Energy in 2001. It should be noted that this paper does not address the technical, environmental, and transportation findings that were also incorporated into the Impact Assessment Report. The paper begins with a brief summary of the bases for Clark County's activities. This is followed by an overview of the methodology and findings from the studies that have been conducted over the last fifteen years in the areas of:

- $\quad$ economic impacts;

- $\quad$ property value impacts;

- $\quad$ public safety impacts;

- $\quad$ other non-public safety governmental impacts: and

- $\quad$ public involvement.

\subsection{Bases}

Since 1983 Clark County has been recognized as an active participant in monitoring the DOE Yucca Mountain nuclear waste program efforts. In 1987, DOE officially designated Clark County as an "Affected Unit of Local Government (AULG)" under provisions of the NWPAA, when the search for a geologic repository study site was reduced to only one alternative: Yucca Mountain. The AULG designation was an acknowledgement by the federal government that activities associated with the Yucca Mountain Project could result in considerable impacts to our residents and community. In fact, the provisions under the Act enable Clark County to determine "any potential economic, social, public health and safety, and environmental impacts of a repository," 42 U.S.C. Section 10135(c)(1)(B)(i).

In addition to the NWPAA, applicable case law supports Clark County's efforts to fully identify potential impacts. In County of Esmeralda v. Department of Energy, 925 F.2d 1216 ( $9^{\text {th }}$ Cir. 1991), the court stated: "Affected unit status is also meant to ensure that all potential harms from repository operation whatever the current estimate of their probability - are sufficiently studied before Yucca Mountain is approved as a repository."

Further, under the National Environmental Policy Act (NEPA), the DOE is required to follow specific processes for identifying and assessing environmental impacts that may result from the operation of a nuclear waste repository at Yucca Mountain. 


\subsection{Economic impacts}

Clark County, with a land area of over 7,900 square miles, is the fastest growing county in the United States. At the time of the decision to narrow the DOE's search for a suitable site to store high level radioactive nuclear waste (HLNW), Clark County's population was half what it is today, over 1.5 million. Over the next twenty years, the area's population is expected to reach 2.8 million. With more than 35 million visitors annually, the primary engine that drives economic growth is the gaming industry. Also key to Clark County's economic growth are service and construction-oriented businesses.

In a region where the concept of "perception is reality" is particularly marked, the stigma and perception of any danger associated with high level radioactive nuclear waste presents a very real and significant threat to Clark County residents, businesses, and visitors.

Thus, Clark County identified potential effects on the tourism industry of the DOE's proposal to ship high-level waste through Clark County to a repository at Yucca Mountain as a key area for study. In order to identify both the nature and the range of concerns of key tourism leaders, focused, confidential interviews were conducted with 14 gaming executives and a representative of one of their trade associations. The gaming executives represented 10 casinos that generate 95.5\% of the Earnings Before Interest, Taxes, Depreciation, and Amortization (EBITDA) within Clark County's gaming industry.

According to the gaming executives, the current downturn in the U.S. economy was identified as a significant challenge that will likely contribute to slowing growth among this sector in the near term. Overall, however, most of the executives believe that despite short-term cyclical responses to national and worldwide economic conditions, the overall trend for the gaming industry in the absence of high level radioactive nuclear waste shipments is positive. Further, all of the gaming executives interviewed expressed concern that an accident, even a minor one along a route anywhere in Clark County, could have a devastating impact on their business. While some representatives were unsure of the scientific viability of the Yucca Mountain repository, all indicated that under no circumstance should trucks carrying high level radioactive nuclear waste come through Clark County. Several noted that just the transportation of high level radioactive nuclear waste coming from California through Clark County en route to Yucca Mountain, could significantly affect their business in an adverse manner. These industry representatives noted that congestion, particularly on weekends along the California/Nevada transportation corridor, has already proved problematic. They believe the addition of slow moving trucks containing such dangerous wastes will increase the likelihood and severity of an accident, discouraging some Californians from driving to Las Vegas. These representatives stated that Californians make up $30 \%$ of the visitors to Clark County. The increase in congestion along the California/Nevada corridor, combined with rising energy costs, is seen as a significant risk to gaming in Southern Nevada, especially for the Las Vegas downtown casinos.

According to the gaming industry executives the most serious risk is from the stigma that will result if there is a HLNW transportation accident of any kind 
involving the shipment of high level radioactive nuclear waste. These representatives referenced the media coverage that is likely to accompany any incident involving a vehicle transporting HLNW. Several stated that an accident anywhere in Clark County would be reported worldwide and would be linked to Las Vegas because it is the nearest media outlet.

In order to understand how the Yucca Mountain Project might influence visitation rates, a survey of 1,013 visitors was conducted in early December 2001. Among those surveyed, 25\% indicated that just the shipment of high level radioactive nuclear waste through Clark County would affect their decision to visit Las Vegas in the future, even if there were no incidents of any type. Among the $25 \%$ who indicated that the shipments of high level radioactive nuclear waste would affect their decision to visit, $77 \%$ stated that they would reduce their visits and $12 \%$ stated that they would never visit Las Vegas again.

In the event of a HLNW transportation accident, even a minor accident, $37 \%$ of the visitors surveyed indicated that it would affect their decision to visit Las Vegas. Among these visitors, 49\% stated that they would never visit Las Vegas again and $47 \%$ said that the frequency of their visits would decrease. If a serious accident resulting in a release of radiation were to occur, those surveyed indicated that the results would be devastating. Almost $80 \%$ noted that it would affect their decision and of those who stated that it would affect their decision, $62 \%$ stated that they would never visit Las Vegas again and 35\% indicated that they would reduce the frequency of their visits.

\subsection{Property value impacts}

A scenario-based survey methodology of expert's, i.e., Clark County lenders and appraisers, was used to measure the nature and extent of any potential property value change that might occur as a result of the HLNW shipment campaign. The scenarios used in the property value study, are also used as part of the analysis of impacts on both public safety agencies and other governmental agencies within Clark County. These scenarios are described below. In addition, public opinion surveys were conducted to corroborate the findings of the technical experts.

\subsection{Experts survey}

The results of focused interviews with Clark County lenders and appraisers were applied to the assessed valuation data for three groups of land uses within Clark County. UER conducted a survey of 18 Clark County lenders and 35 certified appraisers in May 2000.

Under the first scenario, the appraisers and lenders were asked to evaluate whether there would be any changes in property values along the corridor if "no event" occurred, but there was adverse publicity, particularly, at the onset of the shipment campaign. This scenario was assigned to three discreet residential, commercial, and industrial properties that were characterized in terms of size, location, lease fees, and other factors. The lenders and appraisers were also asked to differentiate the level of impact, if any, that might be experienced at two varying distances along the corridor (within 1 mile of the shipment route and within 1 to 3 miles of shipment routes). A second scenario describes a HLNW 
shipment accident where no release of radiation occurs. The third scenario describes a serious HLNW shipment accident that is accompanied by a release of radiation.

Tables 1 and 2 summarize the results of the property value loss under each of the scenarios as estimated by the Clark County bankers and lenders. According to the lenders and appraisers, residential properties would lose the most value in percentage terms under each of the scenarios. For example, under Scenario 1, when the rates of property value diminution are applied to residential fair market value data at a distance of up to three miles from the Beltway route, the diminution ranges from $\$ 203.2$ million to $\$ 462.5$ million. From the I-15 route, the diminution ranges from $\$ 243.6$ million to $\$ 549.6$ million (Table 1).

What these tables suggest is that among those most experienced with estimating Clark County property values, there is a perception that significant adverse impacts will occur along either of the Clark County routes proposed, for all property types examined, even under the most benign scenario.

The findings also indicate that increasing the severity of events within the scenarios, as illustrated in Scenario 2 and 3, results in significantly larger rates of impact. Under Scenario 3, the most serious accident event evaluated, residential property diminution rises to $\$ 5.3$ billion - $\$ 6.2$ billion within 3 miles of the Beltway route and $\$ 6.2$ billion - $\$ 7.3$ billion within 3 miles of the I-15 route.

While, the many uncertainties surrounding the DOE's proposed HLNW shipment campaign make it impossible to estimate the nature and extent of any property value reductions, there is no doubt that it poses a significant threat to property values in Clark County.

Table 1: Property value diminutions under three scenarios within 3-mile distance of the proposed beltway route.

\begin{tabular}{|l|l|l|}
\hline \multicolumn{2}{|l|}{ Residential } & \multicolumn{2}{|l|}{ Appraisers } \\
\hline Groups & Lenders & $\$ 462,500,346$ \\
\hline Scenario 1 & $\$ 203,219,474$ & $\$ 1,175,472,314$ \\
\hline Scenario 2 & $\$ 646,024,023$ & $\$ 6,203,196,049$ \\
\hline Scenario 3 & $\$ 5,269,739,823$ & \multicolumn{2}{|l|}{} \\
\hline & Commercial & $\$ 14,100,251$ \\
\hline Scenario 1 & $\$ 5,615,300$ & $\$ 33,873,129$ \\
\hline Scenario 2 & $\$ 12,424,417$ & $\$ 189,179,886$ \\
\hline Scenario 3 & $\$ 171,414,257$ & \multicolumn{2}{|l|}{} \\
\hline & Industrial & $\$ 9,518,200$ \\
\hline Scenario 1 & $\$ 5,919,186$ & $\$ 27,680,400$ \\
\hline Scenario 2 & $\$ 15,892,269$ & $\$ 192,465,463$ \\
\hline Scenario 3 & $\$ 125,658,343$ & \\
\hline
\end{tabular}


Table 2: Property value diminutions under three scenarios within 3-miles of the I-15 shipment route, by professional group (Lenders and Appraisers).

\begin{tabular}{|l|l|l|}
\hline & Residential & \multicolumn{2}{|l|}{} \\
\hline Groups & Lenders & Appraisers \\
\hline Scenario 1 & $\$ 243,567,363$ & $\$ 549,526,426$ \\
\hline Scenario 2 & $\$ 772,643,577$ & $\$ 1,392,987,706$ \\
\hline Scenario 3 & $\$ 6,218,675,720$ & $\$ 7,318,862,089$ \\
\hline & Commercial & \\
\hline Scenario 1 & $\$ 21,388,171$ & $\$ 72,531,494$ \\
\hline Scenario 2 & $\$ 76,137,260$ & $\$ 171,126,151$ \\
\hline Scenario 3 & $\$ 704,094,009$ & $\$ 926,894,417$ \\
\hline & Industrial & \\
\hline Scenario 1 & $\$ 14,103,817$ & $\$ 25,012,894$ \\
\hline Scenario 2 & $\$ 54,535,563$ & $\$ 83,790,291$ \\
\hline Scenario 3 & $\$ 361,917,017$ & $\$ 507,543,183$ \\
\hline
\end{tabular}

Table 3: $\quad$ Economic impacts based up property value estimates from years 2010 through 2035.

\begin{tabular}{|c|c|c|}
\hline Economic Losses & Scenario 1 & Scenario 3 \\
\hline & Minimum Impact & Maximum Impact \\
\hline Population & 11,294 & 90,718 \\
\hline Job & 5,393 & 54,429 \\
\hline $\begin{array}{l}\text { Gross Regional Product } \\
\text { Annual } \\
\text { Cumulative*** }\end{array}$ & $\begin{array}{l}\$ 182 \text { million* } \\
\$ 5.6 \text { billion** }\end{array}$ & $\begin{array}{l}\$ 1.4 \text { billion* } \\
\$ 68.1 \text { billion** }\end{array}$ \\
\hline $\begin{array}{l}\text { Disposable Personal Income } \\
\text { Annual } \\
\text { Cumulative*** }\end{array}$ & $\begin{array}{l}\text { \$136 million* } \\
\$ 4.7 \text { billion** }\end{array}$ & $\begin{array}{l}\$ 686 \text { million* } \\
\$ 42.1 \text { billion** }\end{array}$ \\
\hline
\end{tabular}

* Projected for 2010 in constant 1992 dollars.

** All dollars are in constant 1992 dollars due to the REMI model. Therefore, all dollars represented are conservative estimates.

*** For period from 2010 through 2035; dollars are in constant 1992 dollars.

\subsection{Economic losses based upon property values and population estimates}

UNLV's CBER was requested to utilize the results from the lenders and appraisers survey as input into the Regional Economic Model, Inc. (REMI) and 
to compare these outputs to the normal REMI outputs. CBER estimated minimum and maximum impacts on employment, income, expenditures, and population. The REMI model utilizes 1992 dollars. Therefore, all dollars reflected in this section are in 1992 constant dollars. This results in estimates that are extremely conservative as shown in Table 3.

\subsection{Minimum impacts (based upon scenario 1)}

The impacts identified as minimum impacts within Scenario 1 (trucks utilizing the Clark County transportation system without incident) are as follows, Employment would be reduced by 5,393 jobs. Gross Regional Product (Spending) would be reduced by $\$ 185$ million. This is a one-year figure and will be cumulative over the life of the project to $\$ 5.6$ billion. Real Disposable Income would be reduced by $\$ 136$ million for one year. Cumulatively, over the life of the project, losses of Real Disposable Income could exceed \$4.7 billion. Population would be reduced by 11,294 people. This is an average population loss over the life of the project. Of interest to note is that over this last decade, the population within Clark County has never declined and in fact has grown, on average, $6.27 \%$ per year.

\subsection{Maximum impacts (based upon scenario 3)}

The impacts identified as maximum impacts within Scenario 3 (a serious accident including the release of radioactive materials involving the Clark County transportation system) are as follows. Employment would be reduced by 54,429 jobs. It should be noted that this is equivalent to increasing the current unemployment rate by approximately $6.5 \%$ (roughly 10 times the impact under Scenario 1) to more than $13 \%$.

Gross Regional Product (Spending) would be reduced by $\$ 1.4$ billion. This is a one-year figure and will be cumulative over the life of the project to $\$ 68.1$ billion. This is equivalent to the expenditures made by over 30 major hotel properties. Real Disposable Income would be reduced by $\$ 686$ million for one year. Cumulatively, over the life of the project, this figure rises to $\$ 42.1$ billion. Population would be reduced by 90,718 people, more than 8 times the loss under Scenario 1. This is an average population loss over the life of the project. These estimates under Scenario 3 reflect an expected magnitude of impact. However, it is difficult to verify the duration and likelihood of this impact based upon the information provided by the DOE to date.

\subsubsection{Residential survey}

A random survey of 512 Clark County residents was conducted by the Canon Center at University of Nevada Las Vegas (UNLV) in August 2000. The purpose of the survey was to identify the attitudes, opinions, and perceptions of Clark County, Nevada residents regarding property values in Clark County, and to characterize their beliefs about the potential impacts of the proposed shipments on property values along the transportation corridor. 
The survey found that over one-half of the residents of Clark County consider the risk of an accident from the transportation of radioactive wastes to be serious or very serious. Approximately $80 \%$ of the respondents indicated that they were familiar with the proposed Yucca Mountain Project, while 75\% said that they knew about the DOE's plans to ship high level radioactive nuclear waste through Clark County.

Altogether almost $82 \%$ of the respondents stated that a nearby high level radioactive nuclear waste route would either "decrease a lot" or "decrease somewhat" their likelihood of purchasing a residential property. Seventy-eight percent of the respondents utilized negative terms to describe the effects of the proposed high level radioactive nuclear waste shipment campaign through Clark County.

Forty percent of the respondents indicated that commercial property would decrease with another 5.8\% indicating generally "negative effects" on properties. Interestingly, $6.2 \%$ responding to this open-ended question suggested adverse effects on business operations located near these routes. In contrast to the general question on property values, $33.9 \%$ of responses to the question on commercial properties indicated that there would be "no effect" on these values. Almost three-fourths of the respondents declared that they would not consider purchasing property along the transportation routes under any conditions.

Eighty-two percent of the respondents believe such a property would sell for less, than an identical property that is not near such a route; $15 \%$ think it would not make a difference; and only the remaining 3\% believe it would sell for more.

Of the 369 Clark County respondents who expect lower selling prices for homes near shipment routes, the mean expected drop in selling price in Clark County is estimated at approximately $25 \%$ compared to identical homes not near a highway that transports high-level radioactive nuclear waste.

\subsection{Public safety impacts}

The following fiscal impacts reflect an integrated view of impacts to all public safety agencies in Southern Nevada. The integrated impact study does not attempt to estimate the total costs to public safety agencies within Clark County government and its local jurisdictions from the Department of Energy's shipping of high level radioactive nuclear waste. Rather, only the incremental or additional costs to governmental entities that would be directly attributable to the siting of the repository at Yucca Mountain and the subsequent shipping campaign are projected. This fiscal impact study of public safety agencies uses a scenario based case study approach consistent with the survey of bankers and lenders. Public safety personnel were asked to describe how the events would impact their agency. Public safety personnel were then asked to compile a list of resources, training, personnel, equipment, and capital outlays necessary for them to be able to ensure the public health, safety, and welfare and to carry out their agency's mission for each of the three scenarios.

Because of the length of time between now and when shipments may actually begin, the ambiguities surrounding the actual shipment routes and the modal mix, the estimated fiscal projections are tentative. 
Despite the high degree of professionalism and organization, none of the public safety agencies are currently adequately prepared, trained, or equipped to respond to any of the three high level radioactive nuclear waste shipping scenarios used in the study. This finding is consistent with the 1995 Public Safety Advisory Committee's report that examined public safety needs in Clark County.

The current County Emergency Operations Center that would be the focal point of the County's response to an incident involving high level radioactive nuclear waste is only adequate for a very short duration event.

Southern Nevada hospitals are not adequately equipped, nor are personnel properly trained to effectively manage a high level radioactive nuclear waste incident like that contained in Scenario 3. The hospital system is already strained under current needs, and the projected hospital needs for the area are daunting. This system will not be adequate to handle the events described in the scenarios in this study.

The total projected cost to just the public safety agencies examined in this study to be adequately prepared for a Scenario 3 event is $\$ 359,986,630$ (Table 4).

Table 4: Total projected costs by community/county.

\begin{tabular}{|l|l|}
\hline & Cost \\
\hline Clark County & $\$ 274,196,809$ \\
\hline Las Vegas & $\$ 45,158,058$ \\
\hline North Las Vegas & $\$ 23,340,046$ \\
\hline Henderson & $\$ 1,386,929$ \\
\hline Mesquite & $\$ 6,980,411$ \\
\hline Boulder City & $\$ 404,880$ \\
\hline Moapa & $\$ 8,519,497$ \\
\hline Totals & $\$ 359,986,630$ \\
\hline
\end{tabular}

* Las Vegas Metro provides services to both Clark County and the City of Las Vegas

** Because of the projected distance to the high level radioactive nuclear waste shipment corridor, Boulder City estimated impacts only for the Police Department.

*** In Mesquite, Emergency Management is a function of the Fire Department and thus costs are combined under Fire.

The largest projected costs to these public safety agencies fall under the categories of facilities, equipment, personnel, and training. For police services, the projected fiscal cost is over $\$ 72.5$ million for the communities examined in this study. The Fire Departments' projected fiscal costs total over \$275.3 million, and the Offices of Emergency Management fiscal cost projections total over $\$ 12$ million. These cost projections are for the agencies to be prepared for a Scenario 3 incident beginning in 2010. The projections do not include costs that will be recurring such as vehicle and equipment replacement costs or the dollar 
costs of training new employees after 2007. Hence, the fiscal cost projections in the report will tend to underestimate (are conservative) some of the fiscal impacts to the public safety agencies.

Additional Haz/Mat Radiological personnel, training, and equipment are viewed as critical needs among the public safety agencies. The hospitals lack sufficient decontamination facilities, equipment, and trained personnel.

Current planning activities are progressing, regional public safety organizations are beginning to grapple with the problems posed by high level radioactive nuclear waste shipments, and a Southern Nevada hospital system approach is developing with the help of the Clark County Health District. There is a critical need for a strong regional effort to ensure that the County, the municipalities, and the Moapa Band of Paiutes are prepared for high level radioactive nuclear waste shipments. Additional resources for the hospitals and the Health District are not projected in this study, only their training and equipment needs.

\section{References}

[1] Urban Environmental Research, Clark County Property Value Report on the Effects of DOE's Proposal to Ship High Level Radioactive Waste to a Repository at Yucca Mountain, (June 2001).

[2] Urban Environmental Research, Impacts to Clark County Public Safety Agencies Resulting from the Yucca Mountain Project (June 2001).

[3] Urban Environmental Research, Impacts to Clark County Non-Public Safety Governmental Agencies Resulting from the Yucca Mountain Repository, (June 2001).

[4] Urban Environmental Research, Gaming Industry Impacts Resulting from the DOE's Yucca Mountain Proposal (June 2001) 